DOI https://doi.org/10.30525/978-9934-26-183-1-15

\title{
РАДІАЦІЙНИЙ МОНІТОРИНГ ПІДЗЕМНИХ ВОД НА ПРОММАЙДАНЧИКУ КОЛИШНЬОГО ВО «ПРИДНІПРОВСЬКИЙ ХІМІЧНИЙ ЗАВОД»
}

\author{
Юрчин С. В. \\ студент \\ Дніпровський державний аграрно-економічний університет \\ м. Дніпро, Україна
}

Кориченський К. О.

науковий співробітник

Украӥнський гідрометеорологічний інститут

м. Київ, Україна

Лаврова Т. В.

науковий співробітник

Український гідрометеорологічний інститут

м. Київ, Україна

В період з 1948 по 1991 р. на одному із найбільших в Європі колишньому ВО «Придніпровський хімічний завод» (м. Кам'янське) виробляли уранові концентрати. Як результат діяльності підприємства на території майданчика колишнього ВО «ПХЗ» у межах його території, а також на прилеглих територіях було утворено шість «хвостосховищ» відходів переробки уранових руд, а також кілька сховищ відходів уранового виробництва. За оцінками обстеження ДП «Бар'єр» у хвостосховищах було накопичено близько 42 млн. тон залишків гірського виробництва. У складі таких залишків накопичено більше 30 млн тон власно радіоактивних залишків переробки уранових руд, а також мільйони тон відходів виробництва, в яких вміст радіонуклідів природного походження не перевищує рівні безпеки для безумовного звільнення відходів від регуляторного контролю.

Проблема утримання залишків уранового виробництва на майданчику полягає в тому, що відходи накопичувалися у природних депресіях ландшафту без будь-яких інженерних і геохімічних бар'єрів. Покриття хвостосховищ не відповідає вимогам захисних екранів, які повинні не допускати проникнення атмосферних опадів в тіло 
хвостосховищ, а також проникнення кисню, який стимулює окиснення і вилуджування радіонуклідів уранового ряду у підземні води. Як результат відбувається підтоплення хвостового матеріалу, а відповідно розповсюдження ізотопів урану з підземними водами за межі хвостосховищ [ 1, с. 118-119].

Протягом багатьох років моніторингові дослідження на майданчику колишнього ВО «ПХЗ» виконувалися співробітниками ДП «Бар'єр» і Українського гідрометеорологічного інституту (УкрГМІ) [2]. Спостереження за забрудненням підземних вод стали однією з її обов’язкових складових комплесної програми радіаційного моніторингу, що здійснюються за науково-методичним керівництвом науковців 3 інституту геологічних наук України [3] .

Аналітичні дослідження по визначенню гідрохімічного складу вод (вміст основних мако-іонів), визначення сумарної $\alpha-$ i $\beta$-активності, активності ізотопів урану-238, урану-234, радію-226, свинцю-210, полонію-210, в окремі роки вмісту токсичних металів (As, $\mathrm{Cd}, \mathrm{Co}, \mathrm{Cr}, \mathrm{Hg}$, $\mathrm{Mn}, \mathrm{Ni}, \mathrm{Pb}, \mathrm{Se}, \mathrm{Ti}, \mathrm{V})$ виконувалися в аналітичній лабораторії відділу радіаційного моніторингу природного середовища УкрГМІ [2]. Для визначення радіологічних показників використовувались методи альфа/бета радіометрії, рідинно-сцинтиляційного лічення, альфа-спектрометрії із відповідними радіохімічними методиками для визначення певних елементів.

Сучасна мережа спостережень за режимом підземних вод на території проммайданчика складає більше 20 спостережницьких свердловин, які розташовані вздовж ліній току основного підземного потоку від основних хвостосховищ.

Завдяки міжнародній підтримки у 2019-2021 рр. було споруджено 12 нових свердловин, що дозволило відновити і розширити мережу моніторингових спостережень за забрудненням підземних вод. Проведені спостереження дозволили виявити нові значні джерела техногенного забруднення геосфери, оцінити на сучасному етапі радіологічні і токсикологічні ризики від забруднення підземних вод, отримати оцінки певного якісного впливу радіоактивно забруднених потоків з території проммайданчика колишнього ВО «ПХЗ» на навколишнє природне середовище порівняно із фоновим забрудненням, додати до відомих проблемних хімічних токсикантів (Mn, Ni) забруднення підземних вод ще $\mathrm{As}, \mathrm{Hg}, \mathrm{Se}, \mathrm{Cd}[4]$.

За даними моніторингових робіт 2005-2021 рр. було показано, що підземні води під хвостосховищами мають підвищений вміст радіонуклідів, особливо ізотопів уран, на деяких ділянках зберігаються 
дуже високі рівні, що перевищують гранично допустимі рівні. Значне розповсюдження 3 підземними водами ізотопів урану простежується від хвостосховищ «Західне», «Центральний Яр». Завдяки невисокій швидкості фільтрації підземних вод від хвостосховища «Дніпровське» в р. Дніпро радіонукліди накопичуються у порових водах під хвостосховищем, а їх об’ємна активність у десятки і сотні разів перевищують гранично допустимі рівні для потенційного водокористування [5 с. 28].

Радіоактивні речовини поступово розвантажуються у р. Коноплянка, що $є$ своєрідним дренажним каналом на території майданчика, а потім у p. Дніпро. Рівні забруднення підземних вод під хвостосховищами $є$ досить високі до 10-100 Бк/л і більше (контрольний індикативний рівень безпеки - 1 Бк/л) [2].

Рівні забруднення вод річки Коноплянка на даний час залишаються невисокими, оскільки процес міграції радіонуклідів із тіла хвостосховищ в сторону розвантаження р. Коноплянка є дуже повільним (8-10 м на рік). Тому, протягом найближчих 100 і більше років суттєвої зміни в темпах забруднення поверхневих вод у зоні впливу хвостосховищ, не очікується [6, с. 226-227]. Однак, зміни форм надходження радіонуклідів в хвостосховищах і руйнування поверхневого покриття може суттєво прискорити процес вимивання радіонуклідів.

Результати консервативних оцінок впливу таких джерел забруднення на забруднення підземних вод і поверхневого стоку показали, що темпи міграції урану з інфільтраційними водами у підземні горизонти суттєво залежать від окисно-відновного потенціалу (Eh), рівню кислотності $(\mathrm{pH})$, гідрохімічного складу підземних вод та сорбційних властивостей грунту. Використовуючи методи геохімічного моделювання, було встановлено, що міграційні властивості урану в тілі хвостосховищ суттєво залежать від типу комплексних сполук урану в порових водах тіла хвостосховища [5, с. 278].

Результати моніторингу за тривалий період 2005-2017 рр. показали, що розширення ореолу забруднення підземних вод за межі хвостосховищ відбувається дуже повільно. Розширення фронту забруднення вод із зон розташування хвостосховищ, які знаходяться на схилах верхньої тераси р. Дніпра до місця їх розвантаження, за оцінками фахівців ІГН НАНУ складає від 50 до 70 років, тоді як період протягом якого уран у розчинних формах може досягти р. Дніпра оцінено до 200 р. і більше [6]. Такі оцінки виконано за результатами математичного моделювання. Натомість, можливі невизначеності таких прогнозів, мають коригуватися результатами моніторингу підземних вод на майданчику. 
Дослідження за участю автора, які виконувалися в рамках програм моніторингу на майданчику колишнього ВО «ПХЗ» дозволяють також визначити фактори, які можуть стимулювати прискорення виносу радіонуклідів у підземних водах а алювіальних грунтах під тілом хвостосховищ, зокрема, про вміст сульфатів і карбонатів, а також розчинних металів у підземних водах.

Проблема забруднення підземних вод на території колишнього ВО «ПХЗ» $є$ важливою та вимагає проведення регулярного моніторингу підземних та поверхневих вод. Розвиток мережі моніторингових досліджень дозволить більш чітко оконтурити джерела забруднення та дати інформацію для прийняття рішень щодо реабілітаційних заходів на цій території.

\section{Література:}

1. Lavrova, T. \& Voitsekhovych, O. Radioecological assessment and remediation planning at the former uranium milling facilities at the Pridnieprovsky Chemical Plant in Ukraine. J. Env. Radioactivity, Issue 115, 2013, pp. 118-123.

2. Voitsekhovych, $\mathrm{O}$. et al. Carrying the observations of changing state of environmental pollution in uranium facilities and their sanitary protection zone and environmental impact assessment of such facilities, Kyiv: Center for Monitoring Studies and Environmental Technologies - «Ecomonitor» LLC., 2011 [Звіт]

3. Ткаченко К.Ю., Скальський О.С., Бугай Д.О., Лаврова Т.В., Процак В.П., Кубко Ю.I. Моніторинг техногенного забруднення підземних і поверхневих вод в зоні впливу уранових хвостосховищ Придніпровського хімічного заводу (м. Кам'янське). Геологічний журнал. 2020.372 (3). С. 17-35.

4. Д.О. Бугай, Б.Ю. Заноз, Т.В. Лаврова, К.О. Кориченський, Ю.І. Кубко, Р. Авіла, Ю.М. Рець. Розвиток системи моніторингу підземних вод у зоні впливу об'єктів спадщини уранового виробництва «Придніпровського хімічного заводу». Геологічний журнал, 2021. № 4.

5. Korychenskyi K.O., et al. Speciation and mobility of uranium in tailings materials at the U-production legacy site in Ukraine. Nucl. Phys. At. Energy., Issue 19, 2018, pp. 270-279.

6. Skalskyy O., Bugai D., Voitsekhovitch O. et al. Groundwater monitoring data and screening radionuclide transport modeling analyses for the uranium mill tailings at the Pridneprovsky Chemical Plant Site (Dneprodzerginsk, Ukraine). The New Uranium Mining Boom: Challenge and lessons learned. Berlin: Springer. 2011. P. 219-228. 